\title{
Redução da infecção da corrente sanguínea: missão impossivel?
}

Autores: Silvia Castro Caruso Christ, Flavia Naif Andrieli, Patrícia Dantas da Silva Rebelo, Fernando José da Silva Ramos.

BP - A Beneficência Portuguesa de São Paulo

\section{Introdução}

A infecção da corrente sanguínea associada à cateter venoso central (IPCS) está relacionada a elevada mortalidade, aumento de custos e tempo de internação, sendo também a infecção associada a cuidados de saúde de maior potencial preventivo. 0 monitoramento desta infecção é realizado através da densidade de incidência (DI), refletindo a qualidade da assistência prestada ao paciente. A ocorrência de três casos consecutivos de IPCS na Unidade de Terapia Intensiva do BP Mirante fez com que a meta estipulada para 2017 não fosse atingida, então identificamos a necessidade de compartilhar algumas ações e reforçar as medidas de prevenção garantindo assim a segurança dos pacientes.

\section{Objetivo}

Implementar medidas para redução de infecção de corrente sanguínea em uma unidade de terapia intensiva adulto.

\section{Metodologia}

Utilizando a metodologia PDSA, compartilhamos e reforçamos as ações em parceria com a unidade:

- Engajamento da equipe;

- Consolidação do indicador de higienização das mãos;

- Treinamento para validação de coleta do indicador de HM:

- Treinamento de preparo e administração de medicação;

- Indicador estratégico;

- Bundle de prevenção de infecção de corrente sanguínea.

\section{Resultados}

As ações foram iniciadas no segundo semestre de 2017, gerando resultados sustentáveis a partir do início de 2018. O resultado anual de 2017 foi de 1,45 infecções da corrente sanguínea associada a cateter venoso central por mil cateteres dia ( 5 infecções), sendo a meta estipulada de 1,28. Para desafiar toda a equipe, em conjunto com a superintendência, foi estabelecida a meta de 1,1 para o ano de 2018 (redução de 14\%).

Notificamos duas infecções em 2018 (DI anual de 0,54), sem evidência de não conformidades das medidas de prevenção registradas em prontuário e durante análise crítica.
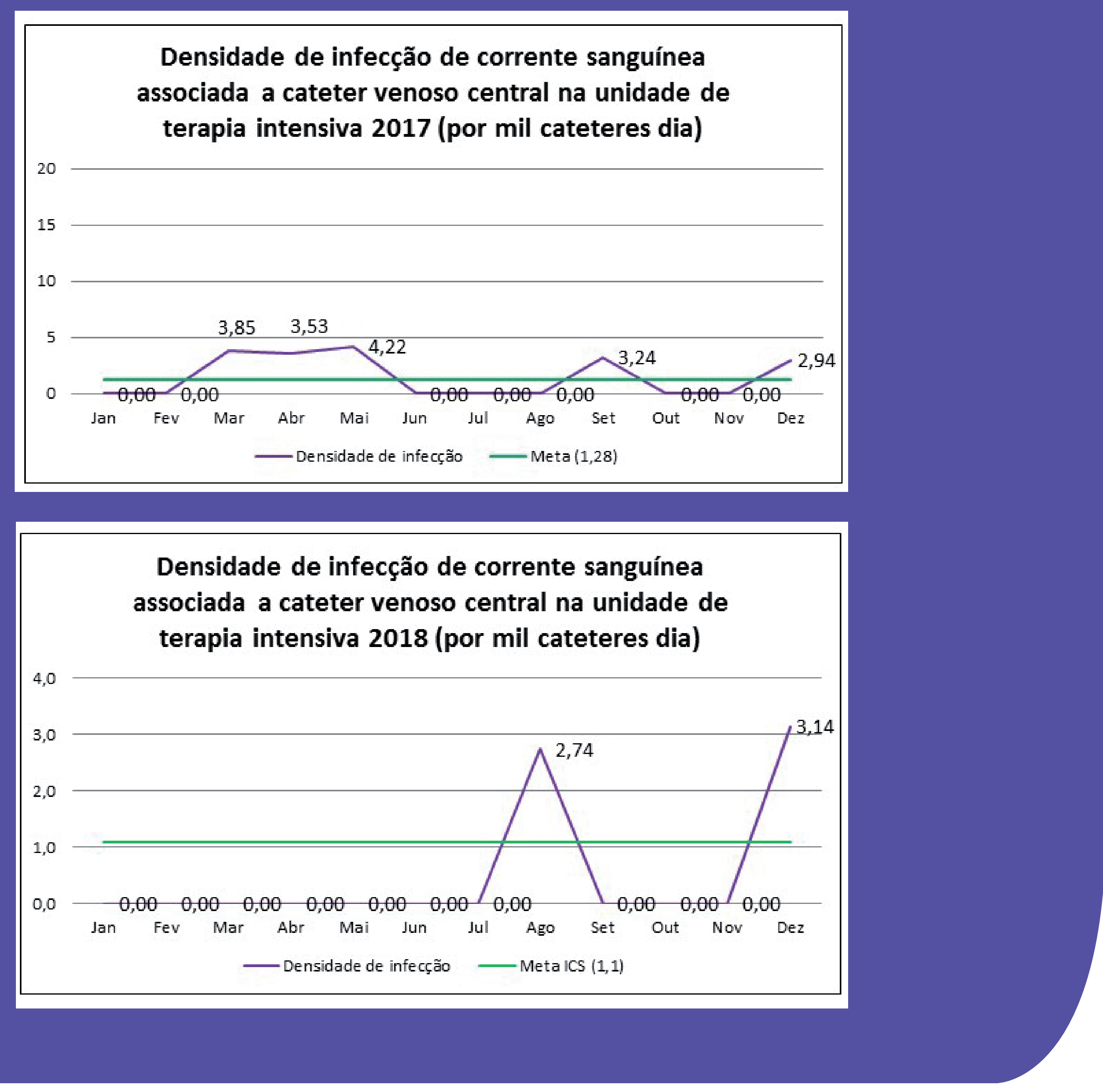

\section{Conclusão}

Concluímos que o compartilhamento das responsabilidades, o reforço contínuo e a parceria com o SCIH contribuiu para a redução da densidade de incidência de infecção de corrente sanguínea associada a cateter venoso central. As ações de empoderamento tornam a equipe engajada para atingir resultados cada vez mais desafiadores, garantindo a qualidade assistencial. 